\title{
Christian Education and Healing Ministry for the Victims of Cyberbullying at School
}

\author{
Dyulius Thomas Bilo ${ }^{1}$, Asmat Purba ${ }^{2}$ \\ 1,2 Sekolah Tinggi Teologi Injili Arastamar (SETIA) Jakarta, Tangerang \\ *Corresponding author.Email: asmatpurba805@gmail.com
}

\begin{abstract}
Online education has brought about many positive interactions among teachers and students, yet one of its negative effects is the increasing rate of cyberbullying. Cyberbullying could occur anywhere and it could bring devastating effects to the victims. This article discusses the important purpose of Christian education to be a means of healing ministry for the students who experience cyberbullying. The content of Christian education should lead to the renewal of the soul through God's grace; thus, the role of Christian educators is not limited to teaching but extended to be a peacemaker who reconciles students who are hostile to one another, an evangelist that spreads the love of Christ to the students, and an agent of healing ministry to the students. In Christian education, teachers should seek to be God's agent of transformation that brings healing and renewal to the soul of the students, especially those who experience cyberbullying. Therefore, the healing ministry is seen as an integral part of Christian education in this paper. This paper uses the library research method and is written under this sequence: first, the calling of the Christian educators; second, Christian education and healing ministry; third, the importance of compassion, empathy, and confrontation in the healing ministry.
\end{abstract}

Keywords: Christian Education, Cyberbullying, Healing Ministry, Online Learning, Transformational Learning

\section{INTRODUCTION}

This article attempts to discuss how Christian educators should involve in the healing ministry, especially in the context of cyberbullying. Christian educators are not just to contribute toward the better understanding of the child as a person, but should also seek to contribute holistically to the development of the children, such as to support, to guide, to reconcile, and also to heal the children, as they model Jesus Christ the Great Teacher who has shown compassion to those who need His presence and ministry.

How can a Christian educator develop himself to not just be a teacher, but also a healer, especially in the case of cyberbullying? This question asks the Christian teacher to play multiple roles for the children. A Christian teacher should work wholeheartedly, be sensitive toward the attitude of the children both inside and outside the class context while attempting to do healing ministry to the children.

According to the Cyber Department of Indonesia (Badan Siber dan Sandi Negara), "cyberbullying" is a continual act of agitation (perundungan) through digital technology that could happen in social media, chatting and gaming platform, and also through cellular phones. Cyberbullying usually happens continually with a motive to terror, provoke anger, or shame the target. Some examples of cyberbullying are spreading false news about the target or distributing shameful pictures of the target, sending threat messages or posting something with offensive words on social media, and using the name of the target to send irresponsible messages to others [1].

Bullying could be defined as an aggressive act that is deliberately done by an individual or a group of people continually to someone who could not defend himself or herself. Seen from this perspective, bullying is an abuse of power. It is also an act of intimidation [2].

The effect of cyberbullying is that the victim would feel attacked all the time, even when he or she is alone. Cyberbullying victim tends to feel cornered and vulnerable all the time. The mental state of the children who experience cyberbullying should be the focus of Christian educators. 


\section{RESEARCH METHOD}

This article employs literature review as the research method. Literature review is defined as a comprehensive presentation of a topic from the most recent literatures in order to strengthen the theoretical foundation through synthesis of many views related to the topic [3]. This article attempts to present the connection between Christian education and healing ministry. To that purpose, this article will first deal with the calling of the Christian educators; second, Christian education and healing ministry; third, the importance of compassion, empathy, and confrontation; and fourth, close with a conclusion.

\section{RESULT AND DISCUSSION}

\subsection{The Calling of the Christian Educators}

The designation of "Christian educators" in this paper is not limited to those who teach Christian religion at school but to all teachers who believe in Christ. Christianity should not be limited to the teaching subject but here refers to the way of living of the teachers as it is expected to be modeled by the students. To do so, Lie argues that a Christian educator should leave behind the myth that to teach is to tell, to tell is to know, and to know is to do, for teaching should not be associated with transferring information alone, but should involve multiple roles and contributions of the teacher. The purpose of Christian education is to transform life holistically toward the image and likeness of Christ [4].

To fulfil that purpose, it is important for a Christian educator to experience the spiritual rebirth in Christ and live out his or her new life in Christ perpetually. A Christian educator should seek God daily in His Word so he or she could be a strong person that is rooted in Christ, thus able to fulfil the calling of bringing about God's transformation to the life of the children. There are three characteristics of spiritual rebirth that every Christian educator should have: first, having a Christian character; second, having sufficient biblical knowledge; third, having a sense of responsibility; and fourth, having the ability to work professionally [5].

The calling of the Christian educator should not be limited to teaching as it is understood in the sense of transferring information per se. But the calling should include the role of teaching, educating, guiding, direct, training, evaluating, supporting, and other roles that might contribute to the holistic development of the students. To teach means to challenge the students continue to respond to God in their life through an absolute dedication to Him. This kind of education requires more than just transferring information. It requires a godly life and the willingness to follow the example of Jesus Christ [6].

\subsection{Christian Education and Healing Ministry}

Given the comprehensive nature of Christian education, healing ministry, especially for the students who have been the victim of cyberbullying should also be the concern of every Christian educator. A Christian educator should be a supporter of those victims so they could be encouraged to stay strong against the influence of cyberbullying, instead of doing something negative to get rid of their bad feelings. The Christian educator should not leave the victims alone with their feelings, they rather should make themselves available during the time of crisis. They could be spiritual mothers and fathers to the students. Through building a strong bond between the Christian educator and the students, the Christian educator could understand the feeling of the students better and the students could be more open to their teachers on what they have been experiencing recently [7].

It has also been advised for the Christian educators to visit the house of the students or to invite the students to their house to create a stronger bond between them. This kind of approach could be more intense in the case of the cyberbullying victims for they need more attention in the process of their healing. Through this process, the values of Christian education that follow the example of Jesus could be applied, for it is impossible to follow the example of Jesus life if the process of education is limited to the classroom alone [8].

A Christian educator is expected to be creative and does not lack with alternatives, for he or she is not just expected to teach but also be a counselor for the students. It requires discipline, diligence, patience, humility and willingness to be a guide for the students. In case of cyberbullying, it is important for both the counselor and the counselee to understand that God's grace is enough even though in weakness (1 Cor. 12:9), so the feeling of vulnerability of the students who experience cyberbullying should not be stronger than the feeling of experiencing God's grace. To strengthen the feeling of being loved by God and accepted by God, it is encouraged that the students could be more active in fellowship with other Christians at the church [9]. Even though Christian love and fellowship are powerful remedies for the victims of cyberbullying, it is important to note that such remedies should be experienced continually. There is no instant healing process from being bullied. It takes time and a long process. What Christian educators should ensure in their healing ministry is that they do it continually, and the students could feel that they are progressing to be better persons.

Discipleship is also a way for the students to strengthen their faith so they could fight vulnerabilities they experienced due to cyberbullying. Discipleship is 
living out the teaching of Jesus Christ in daily life communally, and this applies to both the Christian educators and the students. The life after spiritual rebirth should be shown by leaving behind the "old person" in repentance and the willingness to be the disciple of Christ, and to discipline oneself spiritually [10]. For example, in case of feeling vulnerable and worthless as the effect of cyberbullying, students should reflect upon the topic of God's grace during their meditation. This practice should be the spiritual discipline of the students. Through this spiritual discipline, the students will experience that their faith becomes stronger and they are ready to fight the negative feelings they have due to cyberbullying. In the case of spiritual discipleship, the role of Christian educators is to monitor the spiritual development of the students. They should make sure that the student is not returning to their old pattern of feelings and behavior, but making progress toward healing.

\subsection{Compassion, Empathy, and Confrontation}

To be involved in healing ministry, Christian educators should have compassion toward the students. A Christian educator should follow the example of Jesus Christ. When Jesus saw those who were sick, oppressed, and suffering, His heart was filled with compassion. Jesus's hand is always extended to those who need healing (Matt. 9:12-13, 36; Luke 10:25-37). A Christian educator should understand that the students that they teach are those who will take the leadership position in the future. Groome reminds every teacher that students are brothers and sisters, fellow pilgrims of the teacher in history. Every student has their own unique story and vision to live out [11].

Every Christian educator should also have empathy. Empathy is the starting point of healing ministry from the teachers to the students. According to Susabda, empathy is a willingness to place oneself in the position of the student. When a teacher shows empathy toward the students, that means the teacher is willing to feel what the student is feeling, trying to understand the understanding of the students, seeing through the student's perspectives, and thinking through the framework of the students. Empathy is for the teacher to place both of the feet in the shoes of the students. Only through empathy, Christian educators could accept and appreciate the students as they are. Empathy requires caring, attention, sincerity, humility, sensitivity, and intensity of communication to understand what the students feel. In the case of healing ministry toward students who experience cyberbullying, teachers should not rely on the account of verbal communication alone, but also the non-verbal communication as the body language, and the facial expression of the students [9].
Christian educators should also involve the method of confrontation in doing healing ministry. Agnes Maria Layantara, a psychologist and a Christian theologian explain that truth confrontation is very important in the process of healing those who are psychologically hurt by others. In this healing method, first, the teacher should lead the students to the Great Counselor which is Jesus Christ to accept the new life. Second, the teacher should lead the students to forgive those who did cyberbully to them. The students should understand that they have received full acceptance and forgiveness from Christ, so they also have to forgive and love others. Third, teachers should lead the students to receive a restored self-image. Victims of cyberbullying tend to have a broken selfimage. They tend to believe the negative words that were charged to them on social media. A broken self-image could be confronted with the Bible that says how important human beings are as the image of God, and how humans were created as very good in God's eyes thus they could glorify God through their lives. Fourth, it is also important to affirm the students that they are accepted by God. Fifth, healing is always a process, thus, it is important for the teachers to not try to speed up yet fail to address how the healing process could progress sometimes faster and sometimes slower. Sixth, the teachers should encourage and pray for the students to grow in Christ. Only through spiritual growth, the victims of cyberbullying could be strong once again and could face the threat of cyberbullying in the future by themselves [7].

\section{CONCLUSION}

Cyberbullying is a social evil that should be stopped in any society, especially among the students who are still in their youth age and thus, fragile to the destructive effect of cyberbullying. The calling of the Christian educators is not just to transfer knowledge or teaching that is restricted in the class context but to play the role of life transformation of the students. The transformation should occur both in the class and outside the classroom, and Jesus Christ should be the only model of such a transformation, so the students could spiritually grow to the likeness of Christ. Thus, the role of the Christian educators is multiple. They play the role of peacemaker, spiritual mentor, guide, prayer and spiritual healer for the students. Christian educators are expected to have a passion to see the students, especially those who are victims of cyberbullying grow spiritually and mentally toward healing.

\section{REFERENCES}

[1] B. S. dan S. Negara, "Cara Mengatasi Cyberbullying: Panduan," 2020.

[2] M. Pandia, Mira, and I. T. J. Weismann, "Pengaruh Cyberbullying di Media Sosial terhadap Perilaku 
Reaktif sebagai Pelaku maupun Sebagai Korban Cyberbullying pada Siswa Kristen SMP Nasional Makassar," Jurnal Jaffray, vol. 14, no. 1, pp. 46-7, 2016.

[3] J. Paul and A. R. Criado, "The art of writing literature review: What do we know and what do we need to know?," International Business Review, vol. 29, no. 4, p. 1, Aug. 2020.

[4] T. G. Lie, Generasi ke Generasi. Bandung: PT. Visi Anugerah Indonesia, 2017, p. 228.

[5] J. M. Nainggolan, Pendidikan Berbasis Nila-Nilai Kristiani. Bandung: BMI, 2011, pp. 108-10.

[6] R. W. Pazmino, Fondasi Pendidikan Kristen. Jakarta: BPK Gunung Mulia, 2012, pp. 19-20.

[7] H. Clinebell, Tipe-tipe Dasar Pendampingan dan Konseling Pastoral. Jakarta: BPK Gunung Mulia, 2002, pp. 53-4, 182-3.

[8] S. V. Monsma and S. W. Carlson-Thies, Free to Serve: Protecting the Religious Freedom of Faithbased Organizations. Grand Rapids: Brazos, 2015, p. 105.

[9] Y. B. Susabda, Panduan Pelayanan Konseling melalui Telepon. Jakarta: People Helpers Ministry Indonesia, 2000, pp. 34-6, 72-3.

[10] A. Purba and Rudi, Konsep Pemuridan Mahasiswa Kristen di Perguruan Tinggi. Banten: Desanta Muliavisitama, 2018, p. 20.

[11] T. H. Groome, Pendidikan Agama Kristen. Jakarta: BPK Gunung Mulia, 2010, p. 385. 